\title{
SOME PERSPECTIVES ON THE PROSPECTS FOR JUDICIAL INDEPENDENCE IN POST-1990 AFRICAN CONSTITUTIONS
}

\author{
Charles Manga Fombad*
}

\section{INTRODUCTION}

Constitutional reforms have dominated all political discourse in Africa since the current transition from authoritarian to democratic rule started in the early 1990s. This so-called "third wave" ${ }^{1}$ of democratisation has provoked African politicians and their constitutional engineers to design and introduce new or substantially modified constitutions. In spite of this frantic remodelling of constitutions, Africa's record on constitutionalism has not been a particularly good one. Most post-independence constitutions were quickly abrogated or easily subverted, suspended or brazenly ignored at the whims of African leaders. The new post 1990 constitutions appear to be an attempt not only to

\footnotetext{
* LIC-EN-DRT (UN OF Y’DE), LLM, PhD, (UN OF LONDON), Associate Professor Department of Law, University of Botswana, UB 00705 Gabarone Botswana

${ }^{1}$ Samuel Huntingdon coined the expression in, The third wave: Democratization in the late twentieth century. Norma, OK, University of Oklahoma Press (1991), pp 15-16. He defines a "wave of democratization" simply as "a group of transitions from nondemocratic to democratic regimes that occur within a specified period of time and that significantly out-number transitions in the opposite direction during that period." $\mathrm{He}$ identifies two previous waves of democratization: a long, slow wave from 1828-1926, and a second wave from 1943-1962. Most consider the "third wave" to have started in the 1970s, although it only reached African shores in the late 1980s and early 1990s, in what Larry Diamond and others such as Julius Ihonvbere and Terisa Turner call "second liberation" or "second revolution”. Larry Diamond, Developing democracy in Africa: African and international perspectives, presented at the Workshop on Democracy in Africa in comparative perspective, at Stanford University (27April, 2001), at http://democracy.stanford.edu/Seminar/DiamondAfrica.htm; see also Larry Diamond, "Is the third wave over?" 7 Journal of Democracy, (1996), 20, 20-21 and Larry Diamond et al (eds), in Consolidating the third wave of democracies. Baltimore, John Hopkins University Press (1997); and Julius Ihonvbere and Terisa Turner, “Africa's second revolution in the 1990s,” Security Dialogue (1993), 349-352.
} 
break away from the dark era of authoritarianism but also to usher the continent into a new era of constitutionalism, ${ }^{2}$ respect for the rule of law and democracy.

The existence of an independent judiciary is one of the core elements of modern constitutionalism and a cornerstone of democracy and good governance. Before 1990, the judiciary in most African countries had been reduced into the handmaiden of the various dictatorial regimes in place and was thus incapable of operating effectively either as a guardian of the constitution, the protector of human rights or an impartial enforcer of the rule of law. Judicial independence is now well established as a cardinal feature of the liberal democracy $^{3}$ that many contemporary African regimes purport to have established.

The struggle for judicial independence is occurring throughout the world, not only in the transitional democracies in Africa, but also in the advanced democracies such as the US, Britain, France, Germany and Japan. This is not surprising because judicial independence has never been a condition that is established fully or that is enjoyed without debate, controversy or challenge. ${ }^{4}$ It is, like democracy itself, an ideal to which all modern civilised states should aspire to attain. It is so fundamental that an American judge has observed that "the US Constitution would be just a piece of paper today if there were not independent judges to enforce it." 5

Almost all African post-1990 new or revised constitutions provide not only for a separation of powers but also for an independent judiciary. Independent courts are indeed crucial to the efforts to establish and sustain a constitutional ethos and respect for the rule of law in many of the continent's fragile and faltering democracies, where the threat of regression to the dictatorships of

\footnotetext{
${ }^{2}$ For the meaning of the rather complex concept of "constitutionalism", see, Charles Manga Fombad, "Post 1990 constitutional reforms in Africa and the prospects for constitutionalism.” (Forthcoming in A G Nhema and P T Zelaza, African conflicts: Management, resolution and post-conflict recovery and development; and, Louis Henkin, "Elements of constitutionalism," 60 The Review (1998), 11-22.

${ }^{3}$ For the difference between liberal democracy and other forms of democracy, see, Giovanni Sartori, Democratic Theory. Detroit, Wayne State University Press (1962).

${ }^{4}$ See, Peter H Russell, “Judicial independence in comparative perspective,” in Peter H. Russell and David M O’ Brien, Judicial independence in the age of democracy. Critical perspectives from around the world. Charlottesville, University of Virginia (2001), at p 301

${ }^{5}$ See the Hon Richard Arnold, "Should more limits be placed on the federal judiciary: No,” Spectrums (1997), at p 29.
} 
yesteryears remains potent. One major lesson that can be learnt from post World War II Europe is the fact that the bill of rights without some independent judiciary is useless against totalitarian dictators. ${ }^{6}$

This paper examines a number of African constitutions which reflect the main Western constitutional models and traditions that have been received on the continent to see what the prospects for judicial independence are. Whilst recognising the difficulties of making such an assessment, it is contended that the prospects for judicial independence, which in turn enhances the prospects for constitutionalism and democratic consolidation, are considerably enhanced when there are constitutional provisions that entrench this. It is doubtful whether in the absence of carefully worded constitutional provisions providing for this, the actual implementation of a constitution would in itself facilitate the emergence of an independent judiciary. At this critical stage of Africa's fragile democratic transition, when the chances of backsliding are quite high, a constitutional commitment to judicial independence may provide the climate for genuine democracy, political stability and respect for the rule of law.

\section{THE MEANING OF JUDICIAL INDEPENDENCE}

Despite the abundant literature on the subject, ${ }^{7}$ there is no consensus amongst scholars on what exactly is meant by judicial independence. The main definitional problem is that judicial independence is a relative, and not an absolute concept. It does not refer to a single kind of relationship or something that a judicial system "has" or "does not have," but rather what it may have "more of it" or "less of it." 8

Be that as it may, most scholars do agree that a truly independent judiciary must have at least three characteristics viz, first, that it is impartial, second, that its decisions are accepted by all and third, that it is free from undue influence. To this three, must be added a fourth, that it must be capable of rendering justice on all issues of substantial legal and constitutional importance. ${ }^{9}$ From

\footnotetext{
${ }^{6}$ See, C.J. Friedrich, The impact of the American constitution abroad. Boston, Boston University Press (1967), at p 145.

7 See in particular, Christopher M. Larkins, “Judicial independence and democratization: A theoretical and conceptual analysis," 44 American Journal of Comparative Law (1996), 608-611.

8 See, The Asian Development Bank, Judicial independence project, "Judicial independence overview and country-level summaries,"

${ }^{9}$ Adopted from the definition of Christopher M. Larkins, op cit at p 611.
} 


\section{THE DENNING LAW JOURNAL}

this perspective, an independent judiciary can be defined as one that is free to render justice on all issues of substantial legal and constitutional importance, fairly, impartially, in accordance with the law, without threat, fear of reprisal, intimidation or any other undue influence or consideration.

Impartiality encompasses the idea that judges should be both individually and collectively autonomous and base their decisions purely on the law and the facts and not yield to any pressure from the parties. At the heart of judicial autonomy is the need for judges to be able to act as neutral third parties with no bias towards the parties irrespective of their economic, social and political status in society. The second characteristics, the need for judicial decisions once rendered to be respected by all, is what has been referred to as "social legitimacy." 10 This involves the capacity of judicial institutions to engender the belief that they deserve obedience and trust. It is this social trust and credibility in justice done and being seen to be done that justifies the state's monopoly of all forms of legal force to enforce judicial decisions. The third element is the absence of "undue" interference or what has also been referred to as "political insularity." 11 Governments pose the most serious threat to judicial independence, not only because of their potential interest in the outcome of a myriad of cases but also because of the enormous power it has and can exercise over judges. Judges therefore need to be insulated from any threats or manipulation that may force them to act unjustly in favour of the state. The emphasis however, is on "undue influences," whether external or internal, which may undermine the judge's capacity to adjudicate in strict conformity with the facts and the law. Some internal influences, such as exchanges between judges through memoranda and conferences on a matter they are handling, as well as external influences, such as reliance on the critical writings of scholars, is not only unavoidable but desirable in the adjudication process. Thus, as Peter Russell rightly points out, to formulate the principle of judicial independence in a way that requires judges to be totally uninfluenced by anybody whatsoever is totally unrealistic. ${ }^{12}$ Absolute judicial insularity is therefore impossible and undesirable. Judges cannot operate in total isolation of the political system but have to be appointed or elected to their positions, paid a salary and made accountable as every other person in society. Judicial

${ }^{10}$ See, the Asian judicial independence project, op cit, at p 14.

${ }^{11}$ See, Owen Fiss “The limits of judicial independence," 25 University of Miami InterAmerican Law Review (1993), 59-60.

${ }^{12}$ In "Towards a general theory of judicial independence," in Peter H Russell and David M O’Brien, op cit, at p 12. 
independence essentially deals with the relationships that judicial institutions and individual judges should or should not have with other institutions, groups or individuals as well as the behaviour, way of thinking and set of attitudes expected of judges. ${ }^{13}$ With perfect and unobstructed independence impossible, the challenge is usually to see how best impartial justice can be administered within the bounds of unavoidable judicial dependence on all political and social actors in society. Finally, another characteristic, often ignored, is the fact that the judiciary must be capable of rendering justice on all issues of substantial legal and constitutional importance. A judiciary can hardly be considered credibly independent if its jurisdiction is so narrowly defined that it is unable to deal with the crucial legal and constitutional issues that matter in the country.

\section{THE CHALLENGES TO A COMPARATIVE ASSESSMENT OF JUDICIAL INDEPENDENCE}

A few caveats on the general idea of attempting a comparative assessment of judicial independence in many countries needs to be inserted here. Although numerous studies have been carried out on the subject, a number of difficulties in accurately identifying and measuring judicial independence have been observed. Besides the well established fact that the idea of judicial independence itself is a variable "more or less" rather than a "yes or no" concept that does not lend itself to an easy straightforward scientific assessment, three particular problems need to be noted.

First, there is often a difficulty with interpreting the evidence of impartiality, insularity and the scope of a judiciary's authority as an institution. ${ }^{14}$ The constitution of a country might well guarantee judges a high degree of independence but restrict the scope of their authority to regulate the legality of the government's behaviour in certain sensitive areas and thus undermine the effectiveness of the judiciary. The best and often cited example of this is the Spanish judiciary under the authoritarian regime of Francisco Franco. Although the judiciary was relatively free from political interference, many politically-sensitive issues such as labour policy, economic and commercial matters and certain aspects of criminal procedure, were reserved to be handled by special courts which the regime could count on to support its

\footnotetext{
${ }^{13}$ See, ibid at 3-9

14 This point is forcefully developed by Christopher M. Larkins, op cit, at 611-612.
} 
interests. ${ }^{15}$ In the constitutions of almost all Francophone and Luxophone African countries, all questions dealing with the control of the constitutionality of laws are exclusively reserved for special constitutional tribunals, which are basically quasi-administrative bodies often composed of political appointees who are apt to deliver decisions favourable to the government. It is also these partisan bodies that are often given the powers to handle the frequent electoral disputes that have usually arisen after most of the post-1990 multiparty elections that have taken place. The major problem that this has given rise to in these countries is that there is as a result no effective and efficient mechanism for ensuring that the rights and privileges provided for and protected by the constitution are not violated. This also makes it difficult to draw any firm conclusions on the formal guarantees of judicial independence since these could be violated with impunity by the government.

A second problem inheres from the fact that courts do not exist or operate in a vacuum but are subject to some democratic restrictions that inevitably restrict their independence and scope of authority. Most constitutions usually allow restrictions to be imposed in certain circumscribed emergency situations, such as the outbreak of war, civil insurrection and grave natural disasters. The frequent and prolonged declaration of states of emergencies in many African countries often substantially undermines the ability of the judiciary to operate independently especially in dealing with human rights violations. ${ }^{16}$ The quality of judicial independence in any country will therefore depend on the nature of restrictions that may be imposed to deal with emergencies or other special situations that may arise and how often the power to impose these restrictions is exercised.

Another factor is that assessment difficulties are often compounded by some general structural and contextual issues such as the poor training of the judiciary, the poor quality or unavailability of legal services, the inadequacy of courtroom facilities, the lack of essential material resources and a host of other logistical issues, all of which directly or indirectly impact on judicial independence. Because these factors may or may not be present to the same extent in the different countries, merely looking at the legal framework for judicial independence alone without taking into account these factors may not give a fairly accurate picture.

${ }^{15}$ Ibid 612-613.

${ }^{16}$ For a discussion of the effects of extensive powers to impose a state of emergency, see Charles Manga Fombad, “Cameroon's emergency powers: A recipe for (un)constitutional dictatorship?” 48 Journal of African Law (2004), 62-81. 
A number of studies have suggested that some of the difficulties that have arisen in making an accurate comparative assessment of the standards of judicial independence in different countries could be overcome by looking at the outcome of courts or through a careful interpretative exercise in which the structural conditions of the courts are analysed along with the judiciary's functional relationship with other political institutions. ${ }^{17}$ Although this is useful, it is unlikely going to produce a result that will be more accurate. It is doubtful whether it could ever be possible to develop a system of study that would produce an exact and accurate result. It is therefore suggested that what may more usefully be done is to assess the "prospects" for, rather than the actual "existence" of judicial independence. By focusing such an analysis on the constitutional provisions, one will be looking at legal rules that set standards that are less vulnerable to frequent changes and governmental manipulation.

\section{THE BASIC ELEMENTS FOR GAUGING THE PROSPECTS FOR JUDICIAL INDEPENDENCE}

\section{Diverse approaches to judicial independence}

Current African constitutional developments continue to be shaped and influenced by the Western constitutional models that were inherited from the colonial period. Although before 1990 and since then, there have been significant changes to the constitutions that were adopted at independence, these changes have by and large not substantially altered the received models. The British parliamentary or Westminster model, which has been widely adopted in Africa, was actually designed by the Colonial Office in London, and introduced with slight variations to the different former British colonies. The other leading model, the Gaullist model, developed in Paris and based on the Constitution of the French Fifth Republic, was also introduced with slight changes to most Francophone African countries. A variation of the Gaullist model, which reflects the continental Civil law system, has been adopted by Luxophone African countries. It is also worth noting that elements of the American presidential model have been grafted upon the Westminster model adopted in some of the Anglophone African countries. We shall however, briefly examine only the British and French models, both archetypical of the

${ }^{17}$ Ibid 618-619. 
Common Law and Civil Law approaches that have widely been copied in Africa.

Although England is usually regarded as the cradle of the ideal of judicial independence, the judiciary in England is neither a separate nor co-equal branch of government. In fact, the very concept of judicial independence in the English system has been described as an "inchoate one." ${ }^{18}$ Nevertheless, the English have developed an essentially informal but effective system of judicial independence that largely relies on the congeries of statutes, delegated legislation, custom and convention. Historically, the Act of Settlement of 1701, which provided that judges were not to be dismissed without addresses by both houses of Parliament, is usually considered to be the basis of judicial independence in England. Over the centuries, the British reputation for the high standards of judicial independence, marked by such conventional hallmarks as security of tenure, fiscal independence, impartiality and freedom from executive pressure, is due largely to a strong political culture that has consistently provided protection for the judiciary.

By contrast, the French model of judicial independence has been substantially shaped by the obsessive Gallic fear of legal dictatorship through a "government of judges." 19 This approach can be traced to pre-revolutionary France. Because of the bad reputation of royal courts or Parlements before the French revolution, one of the first measures that the revolutionaries took was to break the powers of these courts by subordinating them to the complete control of the executive. Article 64 of the 1958 Constitution of the French Fifth Republic reflects this mistrust of the judiciary when it states that the "President of the Republic is the guardian of the independence of the judiciary," clearly suggesting that the judiciary is not on the same par as the executive but rather below it. This conclusion is reinforced by the powers given to the President to appoint, promote, transfer and dismiss judicial personnel. Although in doing so, he is supposed to receive advice from the Higher Judicial Council, a body whose composition and proceedings he controls, this does not disguise the fact that judicial independence is thereby substantially compromised.

\footnotetext{
${ }^{18}$ Robert Stevens, “Judicial independence in England: A loss of innocence,” in Peter H Russell and David M O’Brien, op cit, at p 155.

19 See, Dennis Tallon, "The constitution and the courts in France," 27 American Journal of Comparative Law (1979), 567-575; John Henry Merryman, "The French deviation," 44 American Journal of Comparative Law (1996), 109-114; and Michael H. Davis, "The law/politics distinction, the French Conseil Constitutionnnel, and the US Supreme Court,” 34 American Journal of Comparative Law (1986), 45-92.
} 


\section{Basic elements of judicial independence}

The general movement by many former African authoritarian regimes towards liberal democracy, which has as one of its essential attributes, an independent judiciary, raises the question whether there are any minimum conditions or basic elements that must be present for the judiciary in any given country to be classified as independent. Although, even in the liberal democracies, such as in Britain and France, as we just saw above, there are differences in approach, there appears to be emerging certain factors that can be categorised as basic elements for gauging the extent to which the prospects for judicial independence in a given country are good or bad.

Various governmental and non-governmental guidelines have been drafted internationally and regionally by experts aimed at fleshing out and agreeing on what could be considered as the basic elements of judicial independence. ${ }^{20}$ Although these documents are not binding, they nevertheless provide evidence of a high level of support for what may be regarded as certain universally agreed core elements of judicial independence.

A number of international and regional instruments make general reference to the concept of judicial independence. ${ }^{21}$ Under the aegis of the United Nations, a number of recommendations have been adopted to clarify the meaning and scope of the notion of judicial independence as guaranteed under the Universal Declaration of Human Rights, 1948 and the International Covenant on Civil and Political Rights, 1966. This is contained in the United Nations Basic Principles on the Independence of the Judiciary, which calls on member states to guarantee judicial independence domestically through

\footnotetext{
${ }^{20}$ For a detailed discussion of this, see Violaine Autheman, "Global best practices: judicial integrity standards and consensus principles,” IFES Rule of Law White Paper Series, http://66.249.93.104/search?q=cache:TVdXJQ6CriwJ:www.ifes.org/searchable/ifes_sit $\mathrm{e} / . .$.

${ }^{21}$ See for example, Article 10 of the Universal Declaration of Human Rights, 1948; Article 14(1) of the International Covenant on Civil and Political Rights, 1966; Article 6(1) of the European Convention for the Protection of Human Rights and Fundamental Freedoms, 1950; Article 8(1) of the Inter-American Convention on Human Rights, 1969; and Article 7(1) of the African Charter on Human and Peoples’ Rights, 1981.
} 
constitutional or legal provisions and highlights certain standards for attaining judicial independence. ${ }^{22}$

At a regional level, there have also been several initiatives. In Africa, the African Commission of Human and Peoples' Rights, established under the African Charter on Human and Peoples' Rights, 1981, after recalling that justice is a core element of democracy, adopted a Recommendation on the Respect and Strengthening of the Independence of the Judiciary in $1996 .{ }^{23}$ The Recommendation calls upon member states of the African Union to meet certain minimum standards to guarantee the independence of the judiciary on the continent. These include sufficient resources, adequate working and living conditions for judges, and the recognition of universal principles of judicial independence. It is also worth noting that in Europe, there are two documents that also seek to clarify the concept of judicial independence and set out its core elements viz, the Recommendation No. R (94)12 on the Independence, Efficiency and Role of Judges, $1993,{ }^{24}$ and the European Charter on the Status of Judges, $1998 .^{25}$

A good number of other guidelines and principles have been adopted by legal experts and judges from a variety of groups ranging from judges and bar associations to international jurist conferences. These efforts have been made either at an international level or at regional level. ${ }^{26}$ For international attempts, the following need to be noted:
i) The Syracuse Principles of $1981 .{ }^{27}$
ii) The New Delhi Standards of 1982. ${ }^{28}$

\footnotetext{
These principles were adopted by the Seventh United Nations Congress on the Prevention of Crime and the Treatment of Offenders held in Milan. See http://www.unhchr.ch/html/menu3/b/h.comp50.htm

23 See African Commission of Human and Peoples' Rights, 19th Session, 03/2604/04/1996, Ouagadougou, Burkina Faso.

24 Adopted during the 518 meeting of the Ministers' Deputies, Council of Europe, http://cm.coe.int/ta/rec/1994/94r12.htm

${ }^{25}$ See, DAC/DOJ (98) 23, 07/08 - 10/1998, Strasbourg, Council of Europe.

${ }^{26}$ See, Violaine Autheman, op cit at p 5.

27 The Syracuse Draft Principles on the Independence of the Judiciary was prepared by a Committee of Jurists and the International Commission of Jurists at Syracuse, Sicily on 25-29 May 1981.
} 
iii) The Montreal Universal Declaration on the Independence of Justice of $1983 .^{29}$

iv) The Universal Charter of the Judge of 1999. ${ }^{30}$

v) The Bangalore principles of Judicial Conduct of $2002 .{ }^{31}$

For regional efforts, there is in Asia, the Tokyo Principles of $1982^{32}$ and the Beijing Principles of $1995 .{ }^{33}$ In Europe, there is the Judges' Charter in Europe of $1993,{ }^{34}$ in Latin America, there is the Caracas Declaration of $1998^{35}$ and in the Middle East, there is the Beirut Declaration of 1999. ${ }^{36}$

28 See, Article 78(2), Namibian Constitution of 1990, http://www.oefre.unibe.ch/law/icl/was00000_.html All subsequent references to the Namibian Constitution should be understood as referring to this Constitution.

${ }^{29}$ The Montreal Universal Declaration on the Independence of Justice was adopted during the 1983 World Conference on the Independence of justice http://66.249.93.104/search?q=cache:TVdXJQ6CriwJ:www.ifes.org/searchable/ifes_sit e/PDF/rule_of_law/ROL_Tool_Kit/WhitePaper_1_FINAL.pdf+montreal+universal+de claration+on+the+independence + of + justice $\& h l=e n$

${ }^{30}$ See, The Universal Charter of the Judge was adopted in 1999 by the International Association of Judges, which brings together national association of judges from around the world.

http://www.iaj-uim.org/ENG/07.html

${ }^{31}$ The Bangalore Principles of Judicial Conduct was adopted by the Judicial Group on Strengthening Judicial Integrity as revised at the Round table meeting of Chief Justices held at the Hague, Netherlands in 2002.

${ }^{32}$ The Statement of Principles of the Independence of the Judiciary in the LAWASIA Region, 1982 was adopted in Tokyo, Japan by LAWASIA Human Rights Standing Committee.

${ }^{33}$ The Statement of Principles of the Independence of the Judiciary in the LAWASIA Region, was adopted in Beijing in 1995 during a Conference of Chief Justices of Asia and the Pacific Region.

${ }^{34}$ The Judges' Charter in Europe was adopted in 1993 by the European Association of Judges.

${ }^{35}$ The Caracas Declaration was adopted during the Ibero-American Summit of Presidents of Supreme Justice Tribunals and Courts, in Caracas, Venezuela in 1998.

${ }^{36}$ The Recommendations of the First Arab Conference on Justice, was adopted during a conference on the judiciary in the Arab region and the challenges in the 21st century in Beirut, Lebanon. 
From these diverse declarations and statements, the core elements of judicial independence that seem to be internationally recognised can be summarised as follows:

i) institutional arrangements for judicial autonomy;

ii) financial arrangements for judicial autonomy;

iii) arrangements for the security of the judicial office;

iv) adequate remuneration of judicial officers;

v) transparent mechanism for judicial appointments; and

vi) judicial accountability. ${ }^{37}$

\section{POST 1990 AFRICAN CONSTITUTIONAL APPROACHES TO JUDICIAL INDEPENDENCE}

It is now necessary to see to what extent the above core elements of judicial independence that are now universally recognised are reflected in some of the post-1990 African constitutions. It is worthwhile pointing out that it is the combined effect of these elements taken as a whole which may provide a basis for judging whether or not, the prospects for judicial independence in any given country are good. Thus, the absence of one element may be sufficiently serious to compromise the chances of the judiciary operating independently. However, the constitutional regime type, whether it is the Westminster, Gaullist or some hybrid must always be borne in mind because this serves to explain the variations in approaches.

\section{Institutional arrangements for judicial autonomy}

The principle of judicial autonomy is considered as a cornerstone of judicial independence and must ideally be enshrined in the constitution or some other laws of the country. It encompasses a number of important rules. These

\footnotetext{
${ }^{37}$ These are fully discussed by Luu Tien Dung, “Judicial independence in transitional countries,” http://www.undporg/oslocentre/dvcsjuly03/DungTienLuu-v2.pdf
} 
include the rule that judges must be impartial and free to decide cases on the basis of the facts and in accordance with the law, without any restrictions, improper influences, inducements, pressures, and threats, direct or indirect from any quarters or for any reasons. It also requires the judiciary to have jurisdiction over all issues of a judicial nature and the exclusive authority to determine whether or not, an issue submitted for its decision is within its competence as defined by law. ${ }^{38}$ Autonomy also requires that the judiciary should be seen to be independent of any undue external influences such as pressure from the legislature, executive, political parties, and the legal profession as well as internal pressure from horizontal and vertical bosses. Impartiality requires that in acting, judges should be influenced by the law and their conscience only.

Judicial autonomy is recognised and protected in different ways by the different African constitutions. The 1996 South African Constitution ${ }^{39}$ deals with this in fairly unambiguous and elaborate terms in Section 165, which states:

1. "The judicial authority of the Republic is vested in the courts.

2. The courts are independent and subject only to the Constitution and the law, which they must apply impartially and without fear, favour or prejudice.

3. No person or organ of state may interfere with the functioning of the courts.

4. Organs of state, through legislative and other measures, must assist and protect the courts to ensure the independence, impartiality, dignity, accessibility and effectiveness of the courts.

5. An order or decision issued by a court binds all persons to whom and organs of state to which it applies.”

A similar approach is adopted in Article 78 of the Namibian Constitution, which also states that the courts are independent and subject only to the

\footnotetext{
${ }^{38}$ See, Principles 1-3 of the United Nations Basic Principles on the Independence of the Judiciary, op cit.

${ }^{39}$ See Act 108 of 1996, and its amendments. All references to the South African Constitution, should be understood as referring to this Constitution.
} 
Constitution and the law. ${ }^{40}$ It also states that "no member of the Cabinet or the legislature or any other person shall interfere with judges or judicial officers in the exercise of their judicial functions," and imposes a duty on all organs of the state to accord such assistance as the courts may require to protect their independence, dignity and effectiveness. ${ }^{41}$ The decisions of courts are declared to be binding on all unless "contradicted by an Act of Parliament lawfully enacted." 42 The Ghanaian Constitution also contains elaborate provisions recognising and protecting the impartiality and autonomy of the judiciary in terms which are very similar to those in the Namibian Constitution. ${ }^{43}$ With perhaps less details, but also designed to ensure judicial autonomy, are a number of provisions in the Angolan ${ }^{44}$ and Mozambican ${ }^{45}$ Constitutions.

The approach adopted in the above constitutions, which differs from that of other Anglophone African countries mainly in the details, is in sharp contrast with that adopted in the constitutions of Francophone African countries. A typical example of the latter is the 1996 amended Cameroon Constitution of 1972. ${ }^{46}$ Judicial autonomy is treated in the same ambivalent and contradictory manner that the French Fifth Republic Constitution treats it. Article 37(2) of the Cameroon Constitution states that "the judicial power shall be independent of the executive and legislative powers," and that judges in discharging their duties shall be governed by the law and their conscience. Any expectations that this recognises and protects judicial impartiality and autonomy are quickly dispelled by Article 37(3), which states that the "President of the Republic shall

40 See, Article 78(2), Namibian Constitution of 1990, http://www.oefre.unibe.ch/law/icl/was00000_html All subsequent references to the Namibian Constitution should be understood as referring to this Constitution.

${ }^{41}$ See, Article 78(3), Namibian Constitution ibid.

${ }^{42}$ See, Article 81 ibid.

43 See, Articles 125 (3) and (5) and 127 (1) and (2) of the Ghanaian Constitution of 1992, PN.D.C.L. 282. All subsequent references to the Ghanaian Constitution should be taken as referring to this Constitution.

44 See, Articles 120, 121 and 123 of the Angolan Constitution of 1992, http://www.oefre.unibe.ch/law/icl/ao00000_html, all subsequent references to the Angolan Constitution should be taken as references to this Constitution.

45 See, Articles 161, 162 and 164 of the Mozambican Constitution of 1990, http://confinder.richmond.edu/MOZ.htm , all subsequent references to the Mozambican Constitution, should be taken as references to this Constitution.

${ }^{46}$ See, Law No. 06 of 18 January 1996 to amend the Constitution of 2 June 1972. All subsequent references to the Cameroon Constitution should be taken as referring to this Constitution. 
guarantee the independence of judicial power.” This clearly indicates that rather than being co-equals, the judiciary is subordinate to the executive, which therefore raises doubts about its ability to operate without undue executive interference and pressure. This approach has been adopted in the Constitutions of most other Francophone African countries. ${ }^{47}$

\section{Financial arrangements for judicial autonomy}

Without adequate resources, it is unlikely that a judiciary can function with any degree of independence and impartiality. The United Nations Basic Principles on the Independence of the Judiciary make it a duty on each member state to provide adequate resources to enable the judiciary to properly perform its functions. ${ }^{48}$ This raises mainly the issue of the process of preparing and decision-making on the budget of the judiciary. As Nicholson points out, "the preparation of judicial estimates by anyone not acting under the direction of the judiciary and the exercise of control by the government over the way in which the courts expend the funds granted to them necessarily poses a potential threat to judicial independence." 49 There are two main approaches that appear to have emerged in preparing judicial budget estimations. The first approach is for the executive to prepare the budget in collaboration with the judiciary. The second approach, which has been followed in a number of African countries, is for the judiciary to prepare the budget and submit it to the executive who may amend it before presenting it to parliament. ${ }^{50}$ This appears to suggest that the judiciary is beginning to gain some influence and command over the judicial budget allocation process.

One of the few countries that say something in its constitution about the role of the judiciary in the budget allocation process is Uganda. However, all it states in Article 128(6) of the Constitution is that the judiciary "shall be selfaccounting and may deal directly with the Ministry of finance in relation to its

47 See, Articles 89 (1) and (2) and 90 of the Mauritanian Constitution of 1991, http://www.oefre.unibe.ch/law/icl/mr00000 .html all subsequent references to the Mauritanian

${ }^{48} \mathrm{Op}$ cit, in Article 7.

${ }^{49}$ In, "Judicial independence and accountability: Can they co-exist?” Australia Law Journal (1993), at p 404.

${ }^{50}$ See, Luu Tien Dung, op cit at p17. 
finances." ${ }^{51}$ The absence of more precise constitutional provisions, such as exists in some Latin American countries, such as Costa Rica, where the budget for the judiciary is guaranteed as a percentage of the national budget in the Constitution, has often made it easy for the judicial budget of African countries to be reduced for purely political reasons. ${ }^{52}$

\section{ARRANGEMENTS FOR THE SECURITY OF THE JUDICIAL OFFICE}

The problem of the security of judicial office raises three important issues viz, the tenure of judicial office, the grounds for removal and the process for the removal or discipline of judicial officers. These critical issues need to be clearly addressed, preferably in the constitution, or in some other law of the country.

\section{The tenure of judicial office}

Security of tenure substantially contributes to insulating judges from external pressure and has rightly been regarded as a sine qua non of judicial independence. Judicial tenures that are too short or mandatory retirement ages at relatively young age could undermine the prestige as well as the institutional independence of the judiciary. An appointment for life or for such fixed period that does not endanger the judges' independence is desirable.

African constitutional approaches vary within two main systems; a career judiciary and non-career judiciary. Francophone African countries have adopted the former, which involves the selection, appointment and promotion of judges from within a judicial or civil service career system. This therefore gives judicial officers life tenure.

Most Anglophone African countries have a non-career system which involves the selection, appointment and promotion of judges by the executive or legislature or a combination of both, with or without the involvement of some stakeholders, such as the Law Society. There are however wide variations which sometimes depend on the duration of the appointment and the level of the court in the hierarchy of courts. Most judges are appointed to serve until 60

${ }^{51}$ See Ugandan Constitution of 1995, http://www.parliament/go.ug/Constitute.htm , all subsequent references to the Ugandan Constitution should be taken as references to this Constitution.

${ }^{52}$ See, Luu Tien Dung, op cit, at p 18. 
or 65 years, but there is always a provision that this could be extended by five years. ${ }^{53}$

\section{Disciplinary and removal grounds}

As Peter Russell aptly puts it, "judicial independence is less at risk at the front end of the personnel process - the appointing end - if there is a strong system of judicial tenure at the back end - the removal end." ${ }^{54}$ Arbitrary and opaque procedures for disciplining and removing judges could easily undermine the independence of the courts. Whilst judges and other judicial personnel, like every other public officer, should be subject to disciplinary measures such as suspension or removal, the grounds that have generally been recognised as legitimate are reasons of incapacity or behaviour that renders them unfit to discharge their duties. ${ }^{55}$ Removal should be made difficult in order to prevent any abuses, so both the concept of incapacity and misbehaviour should be interpreted in a strict manner. Incapacity should be restricted to cases of physical or mental constraints that make judges incapable of carrying out adjudication, whilst misbehaviour should only refer to crimes or offences or gross and repeated acts of neglect that makes the judge unfit to discharge his responsibilities.

Indirect sanctions, such as transfers to remote parts of the country or secondment to an obscure position, have regularly been used as a hidden tool to punish judges. The only way that this can be checked is to state in the law that

${ }^{53}$ For example, in Article 291(2) of the Nigerian Constitution of 1999, states that ordinary judges should retire at 60 but the term could be extended to allow them retire at 65 years, whilst the retirement age of the Supreme Court judges is 65 but this could be extended to allow them hold office until they are 70, http://www.nigerialaw.org/ConstitutionOfTheFederalRepublicOfNigeria.htm, all subsequent references to the Nigerian Constitution should be taken as references to this Constitution. In the Ugandan Constitution, Article 144(1)(a) whilst providing that judicial officers should vacate their offices at 60, allows the Chief Justice, Deputy Chief Justice and Justices of the Supreme Court to hold office until 70 years. In the South African Constitution, the only term of office that is defined is that of judges of the Constitutional Court. According to Section 176, on appointment, they hold office for a non-renewable term of 12 years but must retire at the age of 70 .

${ }^{54}$ Op cit at 16.

${ }^{55}$ See, Principle 18 of the United Nations Basic Principles on the Independence of the Judiciary. 
judges shall not be transferred or seconded to another position or court, without their consent or through a procedure that is fair and transparent.

The issue of disciplining and removing judges is particularly important at this critical stage of the democratic transition in Africa, where judges play an important role in election disputes. The standards and grounds for disciplining and removing judges vary considerably. Even then, it is still possible to note that most Anglophone African constitutions often contain detailed provisions quite similar to those in the United Nations Basic Principles on the Independence of the Judiciary. ${ }^{56}$ One example will suffice. In the Ghanaian Constitution, Article 146(1) states that the judges of the superior courts or Chairpersons of regional tribunals shall not be removed from office except for "stated misbehaviour or incompetence or on ground of inability to perform the functions of [their] ...office arising from infirmity of body or mind." ${ }^{57}$ There are similar provisions in the Botswana, Namibian, Nigerian, South African and Ugandan Constitutions. ${ }^{58}$

By way of contrast, the constitutions in most Francophone and Luxophone African countries merely mention the possibility of disciplinary measures being taken against judges and other judicial officers but reserves the details on this for subsequent laws. ${ }^{59}$ The difficulty with such an approach is that there is no guarantee that such laws will conform to the minimum standards that ensure transparency and prevent any unwarranted interference with the judiciary.

\footnotetext{
${ }^{56}$ See Principles $18-20$, loc. cit

${ }^{57}$ The situation with respect to the removal of other judicial officers is covered by Article 151(1).

${ }^{58}$ See, Section 97(2) of the Botswana Constitution of 1966, as amended in 2002; Article 84(2) of the Namibian Constitution; Section 292(1) of the Nigerian Constitution; Section 177(1) of the South African Constitution and Article 144(1) of the Ugandan Constitution.

${ }^{59}$ For Francophone countries, see Article 37(3) of the Cameroon Constitution; Article 82 of the Malian Constitution; Article 87 of the Moroccan Constitution; and Article 70 of the Gabonese Constitution of 1994, http://www.bdpgabon.org/gouvernement/constitution.shtml , all subsequent references to the Gabonese Constitution, should be taken as referring to this Constitution. For Luxophone countries, see Article 128 of the Angolan Constitution.
} 


\section{DUE PROCESS OF REMOVAL AND DISCIPLINE}

There is now consensus that the best way to prevent the misuse of disciplinary measures against the judiciary is to clearly lay down in advance the procedure to be followed and subject this to an independent judicial review. ${ }^{60}$ The disciplinary process must be transparent, fair, and accessible and include the procedure for filing complaints, carrying out investigations and decisionmaking. Judicial officers have a right to a fair hearing before a decision-making body, which should be independent, especially from the executive. It is particularly important that such a decision-making body is not dominated by the executive or appointees of the executive and it should have representatives from non-judicial institutions to ensure that the judiciary is not totally isolated from the general public. Representatives of judges from all levels of the judiciary are also needed to ensure that the process is not controlled or dominated only by senior judges.

A close analysis of the constitutional provisions dealing with the due process of removal and discipline again shows a remarkable difference in the practice between Francophone and Anglophone African states. In the former, the provisions are generally brief, and do not provide any clear and transparent procedures. The best example of a fairly transparent system is provided for by the South African Constitution. Section 177(1) states that:

1. a judge may be removed from office only if:

(a) the Judicial Service Commission finds that the judge suffers from an incapacity, is grossly incompetent or is guilty of gross misconduct; and

(b) the National Assembly calls for that judge to be removed by a resolution adopted with a supporting vote of at least two thirds of its members.

2. The President must remove a judge from office upon adoption of a resolution calling for that judge to be removed.

60 See, Principle 20, United Nations Basic Principles on the Independence of the Judiciary, op cit 
3. The President, on the advice of the Judicial Service Commission, may suspend a judge who is the subject of a procedure in terms of subsection (1).”

What is particularly significant and novel is the composition of the Judicial Service Commission. ${ }^{61}$ First, its meetings are presided over by the Chief Justice. Second, although it is composed of 24 members, the executive is directly represented by one member, the Cabinet member responsible for the administration of justice or his representative. ${ }^{62}$ The President as head of the national executive may designate four persons, but he must in doing so, consult the leaders of all the parties in the National Assembly. Third, the Constitution makes it clear that the decisions of the Commission are to be arrived at by a majority of its members, to ensure that an influential minority can not impose its will on the majority. This pattern is replicated in the Constitutions of other Anglophone countries such as Ghana, Namibia and Uganda. ${ }^{63}$

Meanwhile, in most Francophone African constitutions, the President as "guarantor of the independence" of the independence decides all disciplinary actions to be taken against judges and other judicial officers. In doing so, these constitutions state that, the President will be "assisted" by the Higher Judicial Council, or a similar body, which is only required to "give him its opinion." The details on the organisation and functioning of these "advisory bodies" are usually left to be defined by subsequent laws. In practice, these bodies are mainly composed of Presidential appointees and the meetings are presided over

\footnotetext{
${ }^{61}$ See, Section 178 of the South African Constitution.

${ }^{62}$ See, Section 178(1)(d).

${ }^{63}$ See, Articles 146-148 of the Ghanaian Constitution; Articles 84-85 of the Namibian Constitution; and Articles 144-147, 151-154 of the Ugandan Constitution. A slightly different approach is provided for in the Botswana Constitution, where Sections 97(3) and 101(3) provide that if the President considers that the question of removing a judge ought to be investigated, he should appoint a tribunal to investigate the matter and advise him as to whether or not the judge ought to be removed. Although not entirely satisfactory because the President alone is given the powers not only to decide whether or not there ought to be an investigation, but also to determine the composition of the tribunal to conduct the enquiry, the main safeguard against any abuse is Sections 97(2) and 101(2) of the Constitution, which lay down a clear and objective criteria for any removal.
} 
by the President himself, with his Minister of Justice acting as Vice Chairman. ${ }^{64}$

\section{Adequate remuneration of judicial officers}

The independence of judges and other judicial officers can be seriously put in jeopardy if the remuneration they receive is so inadequate that they are readily open to bribery or compromising business overtures. Such remuneration needs to be secured by law to prevent them from being arbitrarily decreased, unless this is done as part of an overall economic measure every worker.

Generally, only the constitutions of Anglophone African countries address the issue of judicial remuneration. These often provide that judicial salaries, including allowances, gratuities and pensions are to be charged on the Consolidated Fund. ${ }^{65}$ Some even go further to state that the salaries and other financial benefits shall not be varied to the disadvantage of judicial officers. ${ }^{66}$ Although this means nothing more than that judicial benefits should not be varied in an arbitrary and discriminatory manner, the idea behind protecting their benefits is to ensure that they maintain a minimally respectable standard of living commensurate to their level of responsibilities and status.

\section{Transparent mechanism for judicial appointments}

The mechanism for appointing judges plays a very important role in ensuring a properly functioning and independent judiciary. The emphasis is on an appointment process that is based on an objective and transparent criteria that relies on factors such as qualification, competence and integrity. ${ }^{67}$ There are three main systems of appointments viz, election by the people, appointment by elected politicians and appointment into a professional career judiciary. There are however various variants of used in Africa.

\footnotetext{
${ }^{64}$ See for example, Article 37 (3) of the Cameroon Constitution; and Articles 70-71 of the Gabonese Constitution.

${ }^{65}$ See for example, Section 122 of the Botswana Constitution, Article 127(4) and(5) of the Ghanaian Constitution, and Section 176(3) of the South African Constitution.

${ }^{66}$ See for example, Article 128(5) and (6) of the Ugandan Constitution.

${ }^{67}$ See, Principles 11-12 of the Beijing Statements of the Independence of the Judiciary, op cit; Article 9 of the Universal Charter of the Judge op cit; and Principle 10 of the United Nations Basic Principles on the Independence of the Judiciary, op cit.
} 
Most Anglophone African countries follow the Common Law practice that requires that judicial candidates should have practised for a specified minimum number of years as advocates, barristers or attorneys before they qualify to be considered for appointment as judges. ${ }^{68}$ The Civil Law professional career path approach adopted by most Francophone African countries means that potential candidates for judicial appointments, have to write and pass a competitive examination to go into a school of magistracy where they are trained in judicial skills for a period usually lasting two years. Upon entry into such an institution, the candidate is immediately integrated into the civil service and on graduation may be appointed to serve either as a judge or state prosecutor.

Generally, the constitutions of most Anglophone states clearly spell out in some detail the criteria as well as lay down a transparent procedure for appointments. In both Anglophone and Francophone African constitutions, the actual appointment is made by the executive. This is however based on a "recommendation" by a Judicial Service Commission or similar body, in the case of the former, or the "opinion" of a Higher Judicial Council or similar body, in the case of the latter. A significant difference is that the executive dominates the appointment process in the Higher Judicial Councils in Francophone Africa but not in the Judicial Service Commissions in Anglophone Africa.

Perhaps one of the most transparent appointment procedures is provided in the South African Constitution. It underscores the need for the judiciary to reflect the racial and gender composition of the South African society. ${ }^{69}$ Section 174(3) provides that the President as head of the executive, appoints the President and Deputy President of the Constitutional Court, after consulting the Judicial Service Commission and the leaders of parties represented in the National Assembly, but appoints the Chief Justice and Deputy Chief Justice after consulting the Judicial Service Commission. The other judges of the Constitutional Court are also appointed by the President after consultations with the leaders of parties represented in the National Assembly following an elaborate procedure in which he is required to select the judges from a list of nominees submitted to him by the Judicial Service Commission. ${ }^{70}$ The President appoints judges of all the other courts on the advice of the Judicial

${ }^{68}$ See for example, Article 128(4) of the Ghanaian Constitution and Article 143(1) of the Ugandan Constitution.

${ }^{69}$ See, Section $174(2)$.

${ }^{70}$ See, Section 174 (4). 
Service Commission. ${ }^{71}$ As we noted earlier, the Judicial Service Commission is constituted in such a manner that very few of its 24 members are appointed by the executive. This shows how a carefully structured mechanism for judicial appointment can combine transparency and pluralism in a manner that may totally preclude all the negative aspects of executive interference, but could certainly limit the possibilities of such interference. In Nigeria, the appointments of federal judges is also made by the President, as head of the federal executive, acting on the recommendations of the National Judicial Council but this is subject to confirmation by the Senate. ${ }^{72}$ For state judges, the appointments are made by the Governors, in their capacity as head of the state executives, acting on the recommendations of the National Judicial Council and subject to confirmation by the House of Assembly of the State. ${ }^{73}$ In Botswana, judges are appointed by the President acting on the advice of the Judicial Service Commission, ${ }^{74}$ but rather oddly, in appointing the Chief Justice, who is head of the judiciary and the President of the Court of Appeal, the highest court in the country, he acts alone. ${ }^{75}$

The constitution of a typical Francophone African state provides that judges are to be appointed by the President of the Republic, "assisted" in this task by a Higher Judicial Council or similar body, which as noted above is dominated by executive appointees and only plays the role of "giving" the President its "opinion." "76 A marked departure from the two patterns discussed so far, is that found in the Mozambican and Angolan Constitutions. The Mozambican Constitution provides for both professional and elected judges. The former are to be appointed by the President after consultations with the Supreme Council of the Judiciary, ${ }^{77}$ whilst the latter are to be elected by Parliament, the Assembly of the Republic. ${ }^{78}$ An indication that the elected judges need not be legally trained is given by Article 171(1) of the Constitution, which states that only the professional judges may decide "matters of law," and the role of the

\footnotetext{
${ }^{71}$ See, Section $174(6)$.

${ }^{72}$ See, Sections 231-269 of the Nigerian Constitution.

${ }^{73}$ See, Sections 270-274 ibid.

${ }^{74}$ See, Sections 96(2) and (3) and 100(2) of the Botswana Constitution as amended in 2002.

${ }^{75}$ See, Sections 96(1) and 100(1) ibid.

${ }^{76}$ See for example, Article 37(3) of the Cameroon Constitution, Article 82 of the Malian Constitution and Article 84 of the Moroccan Constitution.

${ }^{77}$ See, Article 170(1) of the Mozambican Constitution.

${ }^{78}$ See, Article 170(4) ibid.
} 
elected judges is reserved to participating in pre-trial hearings. Something very similar is provided for in Article 122 of the Angolan Constitution, which provides for professional judges as well as "citizens assistants." The major drawback of some of these constitutional provisions that allow too much leeway to executives that are prone to interference is that the independence and impartiality of the judiciary is put at great risk.

\section{Judicial accountability}

The growth of judicial powers in liberal democracies has been accompanied by demands for new forms of judicial accountability. ${ }^{79}$ In Africa, the general perception of a high rate of judicial corruption has made the issue of judicial accountability is very important. ${ }^{80}$ Judicial accountability deals with the extent to which, judges whilst being free to decide cases fairly and impartially, can still be made accountable for any serious misconduct. Judicial insulation, which goes with judicial independence, does not mean that judges should be left entirely to their own devices to exploit their positions for private gain. In fact, judicial accountability goes hand in hand with judicial independence but a careful balance must be worked out between the two so that one does not undermine the other. It has been argued that the more independent judiciaries are, the more accountability should be provided to prevent any abuses, provided that the degree of accountability does not endanger their independence. ${ }^{81}$

The key to judicial accountability appears to be transparency. This requires an open and efficient process for dealing with important issues such as discipline, suspension, removal and demotion of judges. As we have seen, some of the processes provided by many constitutions are so executivedominated that misconduct could either be sanctioned or covered up which ever of this best suits the executive at a particular moment. In those countries where the selection and appointment process as well as the process for dealing with judicial misconduct is transparent, such as is the case under the South African Constitution, the judiciary is more likely to employ competent, independent and impartial judges.

\footnotetext{
${ }^{79}$ See, Peter H. Russell, op cit at p 19.

${ }^{80}$ See, Luu Tien Dung, op cit at p 28.

${ }^{81}$ Ibid at p 27.
} 


\section{RATIONALE FOR JUDICIAL INDEPENDENCE}

Several studies have brought out a number of arguments in support of the multiple benefits that come from the existence of an independent judiciary. Although some empirical evidence from some of these studies have suggested that the results are mixed, ${ }^{82}$ the symbolic significance of an independent judiciary, especially for transitional regimes like those in Africa cannot be gainsaid.

The various arguments can be subsumed into one main pertinent point which is that, the constitutionalisation of a credible framework that ensures the independence of the judiciary signifies a clear pre-commitment to certain minimum standards of civilised behaviour for the respect for constitutional norms and the rule of law in a way that will likely promote democratic consolidation. For a continent almost trapped in political instability, economic decline and a deteriorating social order, the prospects of an independent judiciary may not only be reflective of a strong commitment to democracy but may actually be constitutive of it. It is not enough to have constitutional rules that for the first time open the space for political competition. Allowing freedom of expression, freedom of association, free elections and other similar paraphernalia of democracy count for little if there are no guarantees that these rules will be respected and non-compliance sanctioned. Only a genuinely independent judiciary can ensure that the rules of political competition are respected and that a culture of legality that ensures respect for the rule of law emerges. Constitutionalising government through the neutral arbitration of independent judges also provides for the predictability because individuals will know in advance how they stand with respect to the government and how far the latter can go in interfering with their life and activities.

Another positive benefit that may result from an enhanced prospect of an independent judiciary is the possibility of accountability, certainty and predictability in the operation and application of the law. This will also ensure the recognition and enforcement of the various forms of contractual and property rights which could play a crucial role in attracting both domestic and foreign investment desperately needed in many African countries to revive their collapsed economies. It will also prevent the government from arbitrarily

\footnotetext{
${ }^{82}$ See, the Asian judicial independence project, op cit, 15-18 and Matthew Stephenson, "Judicial independence: What it is, How it can be measured, Why it occurs." http://www1.worldbank.org/publicsector/legal/judicialindependence.htm
} 
changing laws or policies at it suit its convenience. Consistency and predictability, especially in the operation and enforcement of the rules on property rights reduces the risks of political opportunism and expediency and provides an incentive for investors. Many crucial matters that determine the decision whether or not to invest can thus be placed beyond the whims and caprices of transient or popular leaders and ruling majorities.

If one of the greatest injuries of Africa's long years of totalitarianism can be said to be the uncertainty that this breed, it can be argued that the institutionalisation of judicial independence, within a framework that offers good prospects for constitutionalism reduces and controls the potentially enormous powers of the state and ruling parties to act arbitrarily. The existence of an independent judiciary signals a state's commitment to constitutionalism, which includes not only respect for the rule of law but also respect for human rights.

\section{CONCLUSION}

The constitutional reforms of the 1990s provided many African governments with an opportunity to adopt many of the fundamental elements that are now considered internationally as crucial in establishing a truly independent judiciary. In spite of the apparent agreement on the basic elements, the concept of judicial independence remains fluid and relative, and this explains the diverse approaches that exist. The analysis of the approach adopted in a number of African constitutions whilst reflecting the continuous influence of the inherited constitutional models shows that there has been considerable progress in certain countries and very little change in others. A number of important conclusions can be drawn from this analysis.

The focus of any serious effort to secure the independence of the judiciary is considerably enhanced by entrenching detailed provisions on what are now accepted as its core principles in the constitution rather than in an ordinary law. This must be so, notwithstanding the well documented fact that Britain, Israel and New Zealand are operating efficiently with functioning independent judiciaries without any entrenched constitutional provisions. The fragility of Africa's democratic transitions and the lack of an ethos, culture or history of constitutionalism necessitate greater clarity. Little scope should be allowed for any executive discretion in such matters. Constitutionalising judicial independence in this way is certainly no guarantee that there will be no 
unwarranted interference by the executive with the judiciary but it will certainly increase the odds against such interference.

Some countries or group of countries have gone further in enhancing the prospects of judicial independence than others. The analysis shows that there is greater scope for interference in Francophone and Luxophone African countries, especially because many countries in the former category, have stuck to the Fifth French Republic constitutional model inherited during the colonial period. Meanwhile, there appears to have been more serious efforts to modernise the Westminster model in most Anglophone countries. However, the South African approach, appears to offer the best prospects for judicial independence and can serve as a model for other African countries.

Most of the post 1990 constitutional changes clearly suggest a greater political awareness and sensitivity to the need for greater openness, accountability, participation and representation. Studies have shown that independent courts have played a major role in the widespread acceptance of governance in many of the advanced democracies. ${ }^{83}$ As African constitutional engineers grapple with the difficult task of crafting constitutions that will meet the needs and aspirations of the people, there is need not only to recognise the role and standards of judicial independence that have emerged after years of serious studies at both international and regional levels but also the fact it is time to limit the excessive and sometimes blind reliance on inherited colonial stereotypes.

\footnotetext{
${ }^{83}$ See, Herbert Jacob, in Herbert Jacob, Erhard Blankenburg et al (eds), Courts, law, and politics in comparative perspective. New Haven, Yale University Press (1996), pp 389-390.
} 